\title{
Systemic Importance of Financial Institutions: Evidence from Asian Countries
}

Amir Rafique*, Muhammad Bilal Asim and Khurram Iqbal

Department of Management Sciences, COMSATS University Islamabad, Pakistan

\begin{abstract}
Purpose of this study is to highlight the systemic importance of non-banking financial institutions. In this study, globally accepted BCBS methodology has been used to identify systemically important banking and non-banking financial institutions of Pakistan, China, Japan and India. Results show that in countries like China and Japan where banks are huge, insurance sector (proxy of NBFIs) is growing and has systemic importance at domestic level but in countries like Pakistan and India, insurance companies have not grown enough to become systemically important at domestic level. The topic of this paper is of considerable interest to both economists and regulators.
\end{abstract}

Keywords: Domestic systemic important financial institution; Global systemic important financial institution; Global financial crisis

\section{Introduction}

Global Financial Crisis (GFC) of 2007-08 exposed the weaknesses of prevailing financial system and showed how failure of large institutions can lead to disastrous consequences for the entire financial system and economy at large. The financial system not only failed to perform its purpose as a reducer and distributor of risk, but it exaggerated risks, triggering an economic contraction that hurt families and businesses around the world [1].

Studies conducted after crisis like Murphy, Dell'Ariccia, and Darolles and Dubecq showed that certain financial institutions are so central to the financial system that their failure can cause shocking damage, both to financial markets and to the economy at large [2-4]. These institutions (too big to fail) are often referred to as "Systemically Important Financial Institutions". Institutions important for global economy are referred as G-SIFI's and domestic important institutions are D-SIFI's. This study focuses on D-SIFI's especially systemic importance of non-banking sector in an economy. The reason of selecting non-banking sector is diversified role of non-banking financial sector in contemporary economic system. Recent crisis showed that prices of products offered by Insurance companies e.g. insurance premiums increase dramatically after global financial crisis, moreover this supply shock extended beyond insurance sector and as a result create a ripple effect [5].

The Financial Stability Board (2009) defined SIFIs as "financial institutions whose distress or catastrophic failure; because of their size, complexity and interconnectedness, would cause significant disruption to the wider financial system and economic activity".

A systemically important financial institution (SIFI) is a bank, insurance company, or other financial institution whose failure might trigger a financial crisis. Researchers in overall world are working on systemic important banks but much work has not been done in nonbanking financial sector [6].

In past years, non-banking sector has grown enough in term of size and interconnectedness with banking sector so assessment of nonbanking sector has also become very important. The present study tries to reveal the systemic importance of non-banking sector especially large insurers using globally accepted BCBS indicator base methodology. Lehman Brother which faced bankruptcy during financial crisis 2008 was the largest Investment Bank of America so we should also focus on non-banking sector as it can also be systemically important for the economy [7].

Unfortunately, not enough work has been done on non-banking sector however US was the early mover in identification of nonbanking financial institutions as systemically important where Financial Stability and Oversight Council (FSOC) has identified three NBFI's as of systemic importance, after that six more insurers have been designated as globally systemically important insurers (G-SII).

Using globally accepted BCBS indicators base methodology we have calculated indicators score (bps) of banks and non-banks (specifically top insurance companies) of countries under study. Based on indicators score this study developed an empirical argument that non-banking financial institutions can also be systemically important. When a non-banking financial institution grows and due to its mode of business it becomes interconnected with the system then it gains systemic importance [8]. Globally regulators are making policies to prevent financial crisis. In today's financial environment NBFI's have expanded their activities that experts think next financial crisis will be initiated from a non-bank [9].

The study is of considerable interest to both economists and regulators. As the failure of financial institution (both banking and nonbanking) in a financial system could adversely affect other industries and can have severe macroeconomic implications as discussed by Chava and Purnanandam [10].

This study has objective to highlight the systemic importance of non-banking financial sector of Asia and we will identify systemically important banking as well as non-banking financial institutions in Pakistan, India, China and Japan. We have chosen these countries because countries other than Pakistan and India have banks in their financial system which has been designated as systemic important

*Corresponding author: Amir Rafique, Department of Management Sciences, COMSATS University Islamabad, Pakistan, Tel: 00923335145221; E-mail: amir.rafique@comsats.edu.pk

Received August 06, 2018; Accepted August 31, 2018; Published September 10, 2018

Citation: Rafique A, Asim MB, Iqbal K (2018) Systemic Importance of Financial Institutions: Evidence from Asian Countries. J Bus Fin Aff 7: 348. doi: 10.4172/21670234.1000348

Copyright: ( 2018 Rafique A, et al. This is an open-access article distributed under the terms of the Creative Commons Attribution License, which permits unrestricted use, distribution, and reproduction in any medium, provided the original author and source are credited. 
in global scenario but these countries have not designated any NBFI as systemic important. Two of these countries have world's biggest insurance sector like china and Japan so selection of these countries will help us to know systemic importance of non-banking sector where this sector has grown. In short the main objective of the study is to identify systemic importance of non-banking financial institution in contemporary financial systems of countries.

The paper is organized in seven sections, including this introduction. Section 4 contains a literature review. Section 5 describes the variables and data used and proposed by BCBS. In Section 6 presented and discussed the results. In Section 7 presented concludes. In Section 6 presented recommendations and the last section presented mandatory tables.

\section{Literature Review}

In literature we found that both financial and non-financial institute are proved as systemically important, extensive work has been done on systemic risk of financial sector because world has come to know catastrophic effects of failure of systemically important financial institutions (SIFI).

Rochet and Tirole [11], Allen and Gale [12], and Freixas et al. [13] defined SIFI as a financial institution having strong inter-linkages with other institutions in the system and whose failure will initiate a ripple effect in the overall financial system. A financial institution gets complex when its operation goes beyond a normal banking transactions like lending, saving, or over-the-counter transactions. It means these authors explored that inter-linkages and complexity of financial institutes cause systemic risk.

Several researches have been conducted to designate the systemically important financial institution and their management not only at global level but at domestic level as well. Policy makers have made efforts to reduce the negative and disastrous impact of systemically important financial institutions on economy at large. Linda explained that due to innovation in mode of business of financial institution and relaxed legal/supervisory requirements for financial institutions [14], these institutions have expanded their risk-taking to achieve supernormal profits, such profit oriented decisions became cause of subprime mortgages which resulted in to global financial crisis.

Systemically Important Financial Institution can be a bank, finance company, insurance company or any other financial institutions whose failure may cause a threat to the overall economy. Banks being the most important financial intermediaries of financial system were focused by policy makers throughout the world but now due to diversification in business of non-banking sector and interconnectivity with banking sector, non-banking sector is also under different rules and regulations [12]. Term SIFI is not confined to banks only but it can be an insurance company, or any other systemic financial institution whose failure can trigger a financial crisis (FSB, 2011).

In 1998, there were 19 systemically important banks on SIFI list but panic was initiated by Long-Term Capital Management (LTMC) which was a hedge fund. Among others AIG a huge insurance company was involved in global financial crisis 2008. So, financial supervisors and regulators should include non-banking financial institutions under the umbrella of SIFI.

Non-bank financial institutions (NBFIs) include a mixed bag of financial institutions. Simply all financial institutions which are not classified as commercial banks are included in NBFI's. They mainly include asset managers, pension funds, insurance companies, leasing companies and mutual funds. Major function of NBFIs is mobilization of savings and facilitation of the financing for different economic activities in a financial system, but NBFIs do not accept deposits from the public at large [15].

Acharya and Richardson argued that systemic risk emerges when there is low overall capitalization of financial sector, both banking and non-banking segments of an economy can become cause of systemic risk [6]. In case of insurance company facing low capitalization, there will be low willingness of company to involve in insurance products which will decrease supply of those insurance products in economy causing increase in price thus loss of economy.

Financial crisis in past has shown that some financial institutions specifically non-banking financial institutions were not subject to regulations and prudential supervision due to which they grew so large, highly leveraged, and so interconnected with the system that their failure threatened to overall financial stability, moreover they created ripple effect in the economy [16].

The argument that the NBFI's specifically the insurance sector is becoming systemically important day by day is becoming stronger, because these firms are offering products against which risk is either non-diversifiable or it can only be diversified at high cost, NBFI's are getting more prone to runs moreover these institutions have expanded their role in the overall financial system [7].

Global progress in identifying systemic important NBFIs at domestic level has not reached advanced stage as compared to D-SIBs, certainly banks are dominant institutions in the financial systems of many domestic economies of world and banks have been the main entities which received assistance during financial crisis but last two global financial crises were initiated from NBFI so identification of systemic important NBFI's is very important to save financial system from failure.

The FSB as the main global institution to screen and give recommendations on supervisory and regulatory frameworks of the global financial system which are used to designate systemically important financial institution, FSB identified a set of indicators (size, interconnectedness with the system, complexity of operations, high substitutability or cross-border activities) to identify systemic importance [17].

Financial institutions which rely on non-conventional sources of income and banks that rely on non-deposit funding and income other than interest income are more profitable but high risk of failure is faced by these institutions [18].

Interconnectedness is widely considered as major determinant of systemic risk Freixas et al. [13] and Allen et al. [19] showed that less interconnected banks are more likely to recover from crisis and contagion effect can be avoided in case of separate clusters of financial institutions. Interconnectedness is most important determinant of systemic risk as it creates ripple effect. Beck and Jonghe documented that concentration of lending of financial institutions specifically banks is one of the major determinates of systemic risk, bank runs are one of the major causes of bank failure and if such bank has a wider spread then this can affect the economy creating ripple effect [20].

Drehmann and Tarashev focus on interbank exposures because it's the major cause of spread and transmission of risk from one institution to other [21]. In another study by Bouwman [22] they pointed out that better capitalized financial institutions are stronger, and they are 
more likely to survive financial crises. Alessandri et al. focus framework developed by Financial Stability Board which included indicators of systemic importance [23]. That framework includes indicators like bank capital, funding, activities and their interaction with bank size as the four most important determinants that can initiate bank risk.

Jain et al. [24] used interconnectedness as a measure of systemic risk and proved that interconnectedness has a positive correlation with the systemic risk of financial institutions and it poses major threat during recessions.

Methodology developed by the BCBS (2011) was then used by FSB to develop a list of systemically important banks at global level [17]. This BCBS indicator base methodology is accepted globally, it has been empirically tested in many countries and it has proven its authenticity.

Brämer and Gischer [25] tested this methodology in Australian banking system, O'Neill B and Xiao [26] used the indicator base framework of Basel Committee on Banking Supervision to designate systemically importance banks of china, Research of Skořepa and Seidler [27] is also one of the examples of conducting indicator-based approach in the Czech national banking sector by modifying proxies that fit well in the domestic financial system. Similarly, Reserve Bank of India (RBI) has designated D-SIB of India using this framework, this assessment will be carried out each year and a new list of D-SIB is published in August each year (RBI, 2014). Malaysian Assessment Board (MAS) (2015) designated systemically important banks of Malaysia at domestic level using BCBS indicators methodology. MAS pointed out that use of indicator base methodology has helped Malaysia to designated D-SIB and this system has strengthened the banking system of Malaysia. Central Bank of Oman (2015) adopted indicator base methodology for identification of D-SIB of Oman. Oman has identified five banks as systemic important domestically. Banks with comparatively low score as compared to top banks but very high score in one category of indicator was also designated D-SIB. Every country which has implemented this methodology is allowed by BCBS to adapt it as per their economy and financial disclosures.

On 16 April 2016, the China Insurance Regulatory Commission (CIRC) has announced that it has started working to designate "domestic systematically important insurers" ("D-SIIs") and CIRC will issue a series of regulations to supervise D-SIIs. The CIRC has not yet declared its timelines for SII designation and issuance of regulations. China has one of the world's largest insurance sectors and a lot of work is required in this sector.

Considering the importance and practical implication of BCBS's indicator base methodology, we have adopted same methodology to identify SIFI's in four countries of Asia at domestic level. As framework has global acceptance and has been successfully applied by many regulatory bodies of the world for designation of SIFI's.

It's worth mentioning here that previous studies have been conducted using BCBS indicator base methodology to identify D-SIB but work on identifying systemic important NBFIs at domestic level has not reached advanced stage as compared to D-SIBs, which is consider in this study.

\section{Data and Methodology}

BCBS methodologies used to calculate basic points of top 10 banks and 10 top insurance companies. Insurance sector is being used as proxy of non-banking sector because insurance companies are streamlined throughout world and constitute major part of non-banking sector.
In this study we used four Asian countries including Pakistan, China, Japan and India. Pakistan and India has no G-SIB but Japan and China has G-SIBs. Because this compared banking and nonbanking sector in countries where banks have global importance and second it compared banking and non-banking sector in countries where banking sector is not big enough as compared to global level. Data required for BCBS methodology is available in Annual Reports of financial institutions and notes about these reposts. We used latest financial statements of year 2017 to extract data required for BCBS methodology.

After last global financial crisis 2008, BCBS under powers granted by FSB developed a methodology for identification of SIFI's. BCBS indicator base methodology has five specific categories of indicators which characterize different aspects of financial institution. This method gives leverage to modify weight of each category according to the local economy.

The Basel Committee proposed that global systemic importance should be identified in terms of impact on global financial economy when a financial institution fails to perform. There are five categories of indicators which measure the impact and spread of failure faced by financial institutions. Each category has specified weightage which can be modified by domestic regulatory authorities for identification of D-SIFI [17]. Those five categories are mentioned below.

- Size

- Interconnectedness

- Substitutability

- Complexity

- Cross Border Activity

\section{Size}

Size of financial institution is considered as a dominant criterion for determining the systemic importance of a financial institution. Damages to the economy in case of failure of financial institution will increase more than proportionately for big institutions. There can be various measures of size of financial institution like total assets, total credit, and total deposits, all these can be used together with equal weightage to measure size.

In this study, we will be using total adjusted assets as measure of size for banking sector. There will be weightage of $25 \%$ for this indicator. For non-banking sector, total revenue is also used as proxy of size. We have used both size and revenue for insurance companies. Assessment methodology as defined by BCBS has weightage of $5 \%$ for size.

\section{Interconnectedness}

Like a contagious disease, financial distress is contagious specially when system is interconnected and institutions are linked together due to mode of business or any other reason. Financial institution's systemic risk is positively related with its level of interconnectedness with the system.

BCBS methodology has identified three indicators for measurement of interconnectedness. We will be using these three indicators to Intra-financial system assets of a financial institutions which include lending's to financial institutions and securities held for trading purpose. Second indicator is intra-financial system liabilities which include borrowings from financial system, deposits, and securities issued etc. Third measure of interconnectedness is whole sale funding 
ratio which is source of financial institution's funds. An institution with high wholesale funding ratio can spread the risk affiliated with that institution. Wholesale funding ratio is calculated by dividing liabilities by total liabilities including retail funding etc. Weight of $25 \%$ is allocated to this indicator and each proxy of this indicator is given equal weight of $8.33 \%$

Proxies of interconnectedness used for insurance companies in this study are reassurance premium received, investment in derivatives and total level 3 assets held by insurance company. For non-banking, financial institution BCBS has reserved high weightage of $45 \%$ we will be using same weightage and divided this weightage among all proxies of interconnectedness.

\section{Substitutability}

It is very appropriate to consider the level of uniqueness of a financial institution because in case of failure of that institution some another institution must replace it for proper working of financial system. If an institution is highly unique due to its mode of business or operations, then systemic importance will be high. Greater the role of a financial institution in specific business line etc. the larger disruption will be caused in case of its failure. As defined by BCBS we will be using multiple proxies for this indicator. Assets held by a financial institution on behalf of its customers as security can disrupt the financial system in case of its failure, so assets under-custody are considered as one measure of substitutability.

Payments cleared and settled through specific institution and underwritten transection by bank is other indicators of substitutability. Number of bank branches and ATMs are also being used as proxy specifically for banking sector of Pakistan. Weightage of $25 \%$ is given to this indicator as well.

For insurance sector, premiums received by an insurance firm from a specific business line is considered as of systemic important because in case of exit of that insurance company from market due to failure that share of insurance services needs to be taken over by another firm. Higher share of insurance company in a specific insurance category make it systemically important. For non-banking sector substitutability has a weightage of $5 \%$ only.

\section{Complexity}

Another criterion for identifying SIFI is complexity of its business operations, as complexity increases then level of difficulty faced by economy in case of its failure increases so it can be considered systemically important.

As identified by BCBS for banking sector we have taken three measures of complexity. Notional value of OTC derivatives that are not cleared through central counterparty, the higher number of noncentrally cleared OTC derivatives a financial institution has entered in to, higher will be the systemic importance of that institution. This is being considered with special context of failure of Lehman Brothers.

Second measure of complexity is value of level III assets held by financial institution. Level III assets are those assets whose fair value is difficult to calculate using models and market prices. This type of assets are not liquid, and fair values can only be estimated so this type of assets cause ambiguity in calculating assets and severe problems are faced by authorities in case of failure.

Trading and available for sale securities held by financial institutions can generate spill over effect in case of fire sale of these securities, this can cause sudden fall in value of these securities and force other institution holding these types of securities to write-down value of these securities. The use of financial institution's securities portfolio for sale is an indicator of the complexity of the business of financial institution and chances of sudden loss which can force that institution to sale these types of securities. Weightage of $25 \%$ is allocated to this indicator which is divided equally to all proxies selected under this indicator.

For insurance sector complexity part of methodology has been given high importance by BCBS. Higher level of diversification in mode of business of non-banking sector makes it complex. Investments in derivatives, revenue from other than insurance, inert industry borrowings and commitments are taken as proxy.

\section{Cross-Jurisdictional activity}

When we need to identify global level systemic importance of a financial institution we take in to account global activity of financial institution under discussion. As we are studying domestic level systemic importance, so we will not consider this indicator in our study.

Weightages of these categories as per original BCBS methodology are mentioned in Tables 1 and 2 for banking and non-banking sectors respectively.

\section{BCBS scoring and threshold}

To calculate the score for an indicator we divide individual bank/ insurance company's amount for individual indicator by the aggregate amount for all institutions in the sample. This amount is then multiplied by 10,000 to convert he indicator score in terms of basis points. The

\begin{tabular}{|c|c|c|c|}
\hline Sr. No. & $\begin{array}{l}\text { BCBS Indicator of } \\
\text { Systemic Risk }\end{array}$ & Proxies & Weightage \\
\hline 1 & Size & Total Assets & 0.25 \\
\hline \multirow{2}{*}{2} & \multirow{2}{*}{ Interconnectedness } & Intra-Financial System Assets & \multirow{2}{*}{0.25} \\
\hline & & Intra-Financial System Liabilities & \\
\hline \multirow{3}{*}{3} & \multirow{3}{*}{ Complexity } & Level 3 Assets & \multirow{3}{*}{0.25} \\
\hline & & Available for Sale Assets & \\
\hline & & OTC Derivatives & \\
\hline \multirow{4}{*}{4} & \multirow{4}{*}{ Substitutability } & Assets under Custody & \multirow{4}{*}{0.25} \\
\hline & & Banks Branches & \\
\hline & & Payments Settlements & \\
\hline & & Number of ATM's & \\
\hline
\end{tabular}

Table 1: BCBS indicators and proxies for banking sector.

\begin{tabular}{|c|c|c|c|}
\hline Sr. No. & $\begin{array}{l}\text { BCBS Indicator of } \\
\text { Systemic Risk }\end{array}$ & $\begin{array}{l}\text { Proxies for Non-Banking } \\
\text { Sector }\end{array}$ & Weightage \\
\hline \multirow{2}{*}{1} & \multirow{2}{*}{ Size } & Total Assets & \multirow{2}{*}{0.05} \\
\hline & & Total Revenues & \\
\hline \multirow{5}{*}{2} & \multirow{5}{*}{ Interconnectedness } & Intra-Financial System Assets & \multirow{5}{*}{0.45} \\
\hline & & $\begin{array}{l}\text { Intra-Financial System } \\
\text { Liabilities }\end{array}$ & \\
\hline & & Reinsurances & \\
\hline & & Derivatives & \\
\hline & & Level 3 Assets & \\
\hline \multirow{4}{*}{3} & \multirow{4}{*}{ Complexity } & Investments in Derivatives & \multirow{4}{*}{0.45} \\
\hline & & Inter-Industry Commitments & \\
\hline & & Inter-Industry Liabilities & \\
\hline & & Revenues other than Insurance & \\
\hline 4 & Substitutability & $\begin{array}{c}\text { Premiums from specific } \\
\text { Business Line }\end{array}$ & 0.05 \\
\hline
\end{tabular}

Table 2: BCBS indicators and proxies for non-banking sector. 
overall score for each financial institution is then calculated by taking a simple average of all category scores.

The BCBS does not prescribe definite threshold levels to differentiate between systemically important financial institutions and non-systemic ones. Central Bank of Oman (2015) has defined systemic importance by a total score of 800 or above. We believe that, the high importance of a bank in one category alone can pose a threat to the system. Accordingly, we also propose that an institution may be classified as systemic if it scores 1,000 or above in any single category regardless of the total score and be required to meet the (stringent) regulations for D-SIBs including requirement of holding any higher capital requirement.

Study in Australian Banking system by Braimer and Gischer took score of 1000 or above as threshold for identifying SIFIs [25]. Exact threshold for identifying SIFI's is debatable and more work in required in this regard.

Although there is no global consensus on threshold level for identification of systemic importance, in this study, will be using threshold of 800 to identify systemic importance of financial institutions.

\section{Results and Discussion}

\section{Results from Pakistan}

In banking sector of Pakistan, no bank has been identified as G-SIB; however, from the results we have found that few banks have domestic systemic importance; failure of these banks can damage economy of the country. By using BCBS methodology we have ranked scores of top ten banks of Pakistan. Our findings show in Table 3 that banks with huge asset size are more systemically important.

Results show that Habib Bank Limited has highest score of 2195 and has enough lead in score making it most systemic important. State owned, National Bank of Pakistan has secured second position in the list by achieving 1551 points. United Bank and Bank Al-Falah Limited occupy third and fourth place in the ranking. These four banks are the big-four systemically important banks of the country.

MCB Bank Limited and Allied Bank Limited are on fifth and sixth position respectively and qualify the threshold criteria of 800 points as defined by Central Bank of Oman to identify Systemically Important Banks at domestic level.

While in Pakistan insurance sector is dominated by State Life Insurance Corporation of Pakistan which has scored 7040, making it the most and in fact the only systemically important financial institution in domestic context.

\begin{tabular}{|c|c|c|}
\hline Sr. No. & Bank Name & Score \\
\hline 1 & Habib Bank Limited & 2,195 \\
\hline 2 & National Bank of Pakistan & 1,551 \\
\hline 3 & United Bank Limited & 1,438 \\
\hline 4 & Bank Al-Falah Limited & 1,170 \\
\hline 5 & MCB Bank Limited & 844 \\
\hline 6 & Allied Bank Limited & 810 \\
\hline 7 & Askari Bank Limited & 594 \\
\hline 8 & Bank Al-Habib Limited & 559 \\
\hline 9 & Faysal Bank Limited & 458 \\
\hline 10 & Bank of Punjab Limited & 380 \\
\hline
\end{tabular}

Table 3: Scores of banks of Pakistan using BCBS methodology.
There is a huge difference in all indicators of State Life and Adamjee Insurance which is on the second spot. Insurance sector especially Life insurance is growing rapidly in the country but due to dominance of state owned company there is no company has grown that much to be considered systemically important even in domestic scenario. Results are shown in Table 4.

As all insurance companies have score less than 800 . So, we can conclude that NBFI's of Pakistan are not big enough to cause much trouble in case of failure so new supervision and regulations are not required of NBFI's but government should implement policies which attract new entrants, because there is a lot of space in non-banking sector of Pakistan.

\section{Results from China}

China's four state owned banks have been identified as Global Systemic Important Banks (G-SIB's) by Financial Stability Board 2013 (FSB). This study has shown in Table 5 same results and we have found that these four banks have highest score among top 10 banks selected for this study.

It is worth noting that China Development Bank and Bank of Communication has also scored very close to Agricultural Bank of China which has been designated as G-SIB, so we can conclude that top six banks should be considered as having systemic importance for the financial system of China. These two banks can be prospectively seen as addition to Global list of Systemically Important Financial institutions because of their high scores. These four banks which include Industrial and Commercial Bank of China, China Commercial Bank, Bank of China and Agriculture Bank of China hold assets worth $80 \%$ of GDP of China.

PingAn Insurance (Group) the only insurance company has been designated as Globally Systemically Important Insurer by Financial Stability Board in 2016. Our results shown in Table 6 that PingAn is on

\begin{tabular}{|c|c|c|}
\hline Sr. No. & Company Name & Score \\
\hline 1 & State Life Pakistan & 7040 \\
\hline 2 & EFU General Insurance Limited & 747 \\
\hline 3 & Adamjee Insurance Company Limited & 726 \\
\hline 4 & Pakistan Reinsurance Company Limited & 555 \\
\hline 5 & Jubilee General Insurance & 347 \\
\hline 6 & IGI Insurance Limited & 313 \\
\hline 7 & Atlas Insurance Limited & 102 \\
\hline 8 & UBL Insurance Ltd & 74 \\
\hline 9 & Askari General Insurance Company Limited & 71 \\
\hline 10 & Crescent Star Insurance Company Ltd & 33 \\
\hline
\end{tabular}

Table 4: Scores of insurance companies of Pakistan using BCBS methodology.

\begin{tabular}{|c|c|c|}
\hline Sr. No. & Bank Name & Score \\
\hline 1 & Industrial and Commercial Bank of China & 1,798 \\
\hline 2 & Bank of China & 1,685 \\
\hline 3 & China Construction Bank & 1,434 \\
\hline 4 & Agricultural Bank of China & 1,089 \\
\hline 5 & China Development Bank Ltd & 1,004 \\
\hline 6 & Bank of Communications & 998 \\
\hline 8 & Industrial Bank Ltd & 668 \\
\hline 9 & CITIC Bank Limited & 573 \\
\hline 10 & Shanghai Pudong Development Bank & 441 \\
\hline
\end{tabular}

Table 5: Scores of banks of China using BCBS methodology. 
top of list having high systemic importance; it shows that it has rightly been designated as G-SII. Four insurance companies after PingAn have scored more than 800 score which is the threshold for identifying SIFIs. So, we have found that top five insurance companies of china are systemically important in domestic context.

\section{Results from Japan}

Using BCBS indicator base methodology we have created an index of top ten banks of country and our results are in coherence with Global Systemic Important Bank's (G-SIB's) list published by Financial Stability Board (FSB).

Today Japan's banking sector is led by Mizuho Financial Group, Sumitomo Mitsui Banking Corporation and Mitsubishi UFJ, these three banks are declared as Globally Systemically Important Banks (Table 7).

It is important to note that Japan Post Bank is second in the list, but it is absent in the list of G-SIB issued by Financial Stability Board. Reason can be the high global activity of other banks in the list and scoring high in that category can lead to G-SIB identification.

Japan's regulatory authorities have also designated two other banks as Domestic Systemically Important Banks which include Nochu Bank and Nomurah Bank. These banks have score of 1027 and 851 respectively and should be supervised.

Top five insurance companies in this index score more than 800 basic score points as shown in Table 8 , so we have an argument to identify these companies as D-SII's and regulatory authorities should make regulations for supervision of identified companies.

Japan's insurance industry has been transformed in past few years where big market player takes competitive advantage by use complex business models. Size, revenues, investments and interlinkage of top insurance companies make them domestically systemic important.

\begin{tabular}{|c|c|c|}
\hline Sr. No. & Company Name & Score \\
\hline 1 & PingAn China Insurance & 2,275 \\
\hline 2 & China taping Insurance & 1,561 \\
\hline 3 & China life insurance & 1,517 \\
\hline 4 & Manulife Insurance & 1,120 \\
\hline 5 & AIA insurance & 862 \\
\hline 6 & China Pacific Insurance & 659 \\
\hline 7 & Peoples insurance China & 640 \\
\hline 8 & Anbang Insurance Company & 699 \\
\hline 9 & New China life insurance & 470 \\
\hline 10 & Hautai Insurance & 197 \\
\hline
\end{tabular}

Table 6: Scores of insurance companies of China using BCBS methodology.

\begin{tabular}{|c|c|c|}
\hline Sr. No. & Bank Name & Score \\
\hline 1 & Mitsubishi UFJ Financial Group & 2,111 \\
\hline 2 & Japan Post Bank & 1,887 \\
\hline 3 & Mizuho Financial Group & 1,579 \\
\hline 4 & Sumitomo Mitsui Financial Group & 1,544 \\
\hline 5 & Nochu Bank & 1,027 \\
\hline 6 & Nomurah Bank & 851 \\
\hline 7 & Fukioka Financial & 353 \\
\hline 8 & Chiba Bank & 270 \\
\hline 9 & Hokuhku Financial & 204 \\
\hline 10 & Ymgf Bank & 173 \\
\hline
\end{tabular}

Table 7: Score of banks of Japan using BCBS methodology.

\section{Results from India}

Banking sector of India has two major banks operating in the country which have competitive edge in the sector due to huge size. These two banks State Bank of India and ICICI Bank hold major portion of the sector. Around 30\% of the industry assets are held by these two banks. Results show that these two banks are on the top of the list. These two banks have been identified as systemically important by Reserve Bank of India (RBI). Scores show that State Bank of India being owned by state has highest score making it systemically important with huge margin. ICIC has also scored high enough to be declared as systemically important.

All other banks in the list fail to score more than 800 to fall in the category of D-SIB's so this study is in coherence with the report published by RBI in 2015 declaring only two D-SIB's. Results also shown us those countries where state has presence and dominance in the banking sector in such economies there are very few systemic banks due to the control of state.

India's Life insurance sector is the world biggest in its size, policies and premiums. In top ten lists of insurance companies of India most of them are life insurers. Like Pakistan state has dominance in insurance sector of the country where top two insurance companies Life Insurance Co-corporation of India (LIC) and New India Assurance Company (ILI) are the largest in life and non-life segments of insurance sector (Tables 9 and 10).

Countries where state owns insurance companies, enjoy competitive edge and trust which help these government companies to grow so other private companies are unable to compete state owned companies. Scores of top ten insurance companies show that no company cross even score of 400 other than top two companies.

\begin{tabular}{|c|c|c|}
\hline Sr. No. & Company Name & Score \\
\hline 1 & Japan Post Insurance & 2,548 \\
\hline 2 & Nippon Life Insurance & 2,169 \\
\hline 3 & DAI-ACHI Insurance & 1,376 \\
\hline 4 & MEIJI Life Insurance & 1,045 \\
\hline 5 & Tokyo Life Insurance & 842 \\
\hline 6 & Sumitomo Life Insurance & 760 \\
\hline 7 & Masad Insurance & 749 \\
\hline 8 & Sompo Insurance & 485 \\
\hline 9 & Sony Life Insurance & 299 \\
\hline 10 & T\&D Life Insurance & 151 \\
\hline
\end{tabular}

Table 8: Score of insurance companies of Japan using BCBS methodology.

\begin{tabular}{|c|c|c|}
\hline Sr. No. & Bank Name & Score \\
\hline 1 & State Bank of India & 3,547 \\
\hline 2 & ICICI Bank & 1,582 \\
\hline 3 & Punjab Bank & 786 \\
\hline 4 & Bank of Baroda & 748 \\
\hline 5 & Canara Bank & 690 \\
\hline 6 & Bank of India & 671 \\
\hline 7 & HDFC Bank & 623 \\
\hline 8 & Industrial Development Bank of India & 527 \\
\hline 9 & AXIX Bank & 508 \\
\hline 10 & Allahabad Bank & 316 \\
\hline
\end{tabular}

Table 9: Score of banks of India using BCBS methodology. 


\begin{tabular}{|c|c|c|}
\hline Sr. No. & Company Name & Score \\
\hline 1 & Life Insurance Co. of India & 6,950 \\
\hline 2 & New India Assurance Company & 1,877 \\
\hline 3 & ICICI Prudential Life Insurance & 333 \\
\hline 4 & HDFC Standard Life Insurance & 322 \\
\hline 5 & BAJAJ Allianz Life Insurance & 139 \\
\hline 6 & SBI Life Insurance & 126 \\
\hline 7 & Birla Sun Life Insurance & 96 \\
\hline 8 & TATA Insurance & 95 \\
\hline 9 & Oriental Insurance & 33 \\
\hline 10 & Aviva Life Insurance & 29 \\
\hline
\end{tabular}

Table 10: Score of insurance companies of India using BCBS methodology.

\section{Conclusion}

With the development of Non-Banking Financial sector, more and more non-banking financial institutions will step in to the financial market and will play vital role in development of economies. Non-banking sector is strengthening day by day and it is upcoming source of systemic risk faced by economies, with passage of time more NBFI's companies will be designated as systemically important due to diversification of offered products, investment in risky assets, interconnectedness and due to expansion of their roles in financial markets.

In the context of recent global financial crisis there is much attention being paid by policy makers towards systemic risk and financial institutions which carry this risk. Banking sector has been focus of regulators but non-banking sector has gained a lot of importance in part few years. Regulatory authorities should develop and strengthen regulation so that crisis arising from such institution can be avoided.

This purpose of this study is to highlight systemic importance of non-banking sector and need of identification of risk affiliated with these institutions. We have seen that in developed countries like Japan and China there are many systemically important insurers. This is because state is not the only huge insurer in these countries so there is growth chance for other insurance companies as well. Banking sector is huge in these countries and banking sector imminent for growth of non-banking sector.

In countries like India and Pakistan where State owns major insurance companies and state enjoys competitive edge, it is very difficult for private insurance companies to become so huge that they can become cause of systemic risk for the economy.

Our study has certain limitation in term of

- Data required for analysis of financial institutions is not available easily like quantum of payments made through a banking system. Financial institutions have not completely adopted change in disclosure requirement after financial crisis which is major limitation to study and decide systemic importance.

- This study is only limited to analysis of insurance industry to study importance of non-banking sector, to develop regulation and supervision rules we need to study all segments of nonbanking sector.

- Development of this threshold for assessment of D-SIFI's is a major research area.

- The study is limited on few Asian countries but can be extended to the other countries and continents of the world.
- Insurance industry is taken as a proxy of non-banking sector to check systemic importance of NBFI's it can be extended to all NBFI's in non-banking sector.

\section{Recommendations}

Financial experts believe that next financial crisis will be triggered from a non-banking financial institution due to diversified mode of business and high level of risk taking activities of non-banking financial institutions, so to avoid any condition like that regulators and analysts should take necessary steps.

Firstly, identifying domestically important financial institutions is most critical to know sectors and institutions which demand necessary regulations and supervision. Without knowledge of systemic importance of different sectors of country cannot be targeted by regulators for proper management.

Identification of SIFI's is complex because of the existence of various factors that shape the systemic characteristics of financial institutions. The historical method for identifying SIFI based on size of financial institutions but recent modification in mode of business of small financial institutes has shown that even small size banks can trigger systemic crisis. So, such identification methodology should be adopted by regulatory bodies which take effect of all factors which can make a financial institution systemically important.

Regulatory bodies should also repeat identification processes after specific period because systemic importance keeps on changing so SIFI identification should be dynamic process. Overall list should be maintained and updated by regulators periodically showing ranked financial institution as per their systemic importance for the economy.

Secondly, during this study we have found that many financial institutions do not give such disclosures of their financials which are used in identification of SIFI's. Standard disclosure requirements should be implemented on all financial institutions specially for nonbanking sector which is far behind in disclosures.

Standard disclosures are important because same proxy of a specific indicator should be used for all firms under study, it will improve transparency in identification of SIFIs and errors can be avoided.

Thirdly, after going through literature regarding identification of SIFI's in domestic context, we have found that there is no consensus on threshold for selecting financial institution for further assessment purpose. There should be a threshold for identification of D-SIFI's as we have well defined threshold in case of G-SIFI's. These days' top financial institutions as per their size are selected for further assessment in domestic context.

\section{References}

1. Geithner T, Summers L (2009) A new financial foundation. Washington Post.

2. Murphy D (2008) Understanding risk: The theory and practice of financial risk management. CRC Press.

3. Dell'Ariccia MG, Mauro MP, Faria MA, Ostry MJD, Di Giovanni J, et al. (2008) Reaping the benefits of financial globalization. Inter Monetary Fund, pp: 1-50.

4. Darolles S, Dubecq S, Gourieroux C (2014) Contagion Analysis in the Banking Sector.

5. Froot KA, O'Connell PG (1999) The pricing of US catastrophe reinsurance. University of Chicago Press, pp: 195-232. 
Citation: Rafique A, Asim MB, Iqbal K (2018) Systemic Importance of Financial Institutions: Evidence from Asian Countries. J Bus Fin Aff 7: 348. doi: 10.4172/2167-0234.1000348

Page 8 of 8

6. Acharya VV, Richardson M (2009) Causes of the financial crisis. Critical Review 21: 195-210.

7. Elliott $P(2013)$ Regulating systemically important financial institutions that are not Banks. Brookings institute paper 9: 30-47.

8. Mustafa M (2014) Firm productivity, exchange rate movements, sources of finance, and export orientation. World Development 54: 204-219.

9. Basutaro P, Goodhart CA (2009) The regulatory response to the financial crisis. Chapters in SUERF Studies, pp: 157-171.

10.Chava S, Purnanandam A (2011) The effect of banking crisis on bank-dependent borrowers. J Financ Econ 99: 1-44.

11. Rochet JC, Tirole J (1996) Interbank lending and systemic risk. J Money Credit Bank 28: 733-762.

12.Allen F, Gale D (2000) Financial contagion. J Polit Econ 108: 1-33.

13.Freixas X, Parigi BM, Rochet JC (2000) Systemic risk, interbank relations, and liquidity provision by the central bank. J Money Credit Bank 32: 611-638.

14.Linda A (2010) Credit risk management in and out of the financial crisis: New approaches to value at risk and other paradigms. ( $3^{\text {rd }}$ edn), Wiley online library, pp: 528.

15.Vittas D (1997) The Argentine pension reform and its relevance for Eastern Europe. World Bank, Financial Sector Development Department.

16. Acharya V, Engle R, Richardson M (2012) Capital shortfall: A new approach to ranking and regulating systemic risks. Am Econ Rev 102: 59-64.
17.BCBS J (2011) Basel III: A global regulatory framework for more resilient banks and banking systems. Basel Committee on Banking supervision, Bank for International Settlements, Basel.

18. Demirgüç-Kunt A, Huizinga $H(2010)$ Bank activity and funding strategies: The impact on risk and returns. J Financ Econ 98: 626-650.

19.Allen F, Babus A, Carletti E (2012) Asset commonality, debt maturity and systemic risk. J Financ Econ 104: 519-534.

20.Beck T, De Jonghe O, Schepens G (2013) Bank competition and stability: Cross-country heterogeneity. J Financ Inter 22: 218-244.

21.Drehmann M, Tarashev NA (2011) Systemic importance: some simple indicators.

22.Bouwman $\mathrm{CH}$, Berger AN (2013) How does capital affect bank performance during financial crises? J Financ Econ 109: 146-176.

23.Alessandri P, Niger J, Mumtaz H (2014) Financial regimes and uncertainty shocks. School of Economics and Finance, Queen Mary, University of London.

24.Jain P, Sander L, Maxell Z (2017) J-REIT Market quality: Impact of high frequency trading and the financial crisis.

25.Brämer P, Gischer H (2011) Domestic systemically important banks: An indicator-based measurement approach for the Australian banking system. Otto-von-Guericke University Magdeburg, Germany.

26. O'Neill B, Xiao JJ (2012) Financial behaviours before and after the financial crisis: Evidence from an online survey.

27.Skořepa M, Seidler J (2013) An additional capital requirement based on the domestic systemic importance of a bank. Czech National Bank Financial Stability Report 2012. pp: 96-102. 